\title{
IMPLEMENTASI TQM \\ (TOTAL QUALITY MANAGEMENT) \\ PADA LEMBAGA PENDIDIKAN
}

\author{
Muhammad Rouf \\ STAI Al Hikmah Tuban \\ rouf.idaman@gmail.com
}

\begin{abstract}
Abstrak
"School/madrasah as an educational institution is an institution that serves as an agent of change to solve the nation's problems. Therefore, in order to produce the quality of education, it is necessary to implement the concept of TQM (Total Quality Management) that in history has successfully led the business world in creating production quality best and can even exceed the satisfaction of customers standard. This study used a qualitative approach with methods of library research. The formulation of the problem involves understanding implementation of TQM, TQM in education, implementation of $T Q M$ principles in educational institutions, the pillars of TQM in educational institutions, measures the implementation of TQM in education and description of the failure in the implementation of TQM. The study results were obtained, among others; The first, implementation of total quality management (TQM) is an implementation or embodiment of a management concept that involves all components in the organization to jointly contribute to the organization's policies oriented to the improvement of product quality to customer satisfaction. Second, in educational institutions, implementation of TQM are used to improve administrative functions and operations, to manage the educational process as a whole, integrate TQM in the curriculum, the use of $T Q M$ in teaching methods in the classroom, the use of TQM for managing research and development activities. In addition, educators must be responsible for their duties proactively, they must develop a problem-solving process that makes sense and can identify and towards the main cause, capable of being the organization model and can measure what's working well and what is not, so that we will get a good system in institutional schools / madrasah. Third, in applying TQM, there are some principles that should be held, among others; focusing on consumers (users of educational services), broad involvement (teachers, staff, students, and community), their measurements, to understand education as a system, and their continuous improvement. Fourth, the five main pillars of TQM here are their products, relying on the process undertaken, the leader who moves in producing quality products, and a commitment among the leaders in the organization. Fifth, steps in implementing TQM in educational institutions include; the preparatory phase, the planning phase and the implementation phase. Sixth, the failure may occur in implementing TQM in educational institutions, if; there is a gap in the commitment of top management, one focus of attention, lack of adequate staff and support, relying solely training, the hope of obtaining results of a moment and force adopt a method that doesn't comply with the requirement."
\end{abstract}

Keywords: Total Quality Management, Lembaga Pendidikan 


\section{PENDAHULUAN}

Pendidikan merupakan modal yang sangat berharga bagi kemajuan suatu bangsa. Melalui pendidikanlah diberikan tumpuan yang sangat besar akan keberlangsungan kehidupan suatu bangsa di masa depan. Hal itu tidak dapat dipungkiri, karena kebodohan atau tingkat SDM (Sumber Daya Manusia) yang rendah adalah awal dari kemiskinan. Nah, melalui pendidikanlah, kemiskinan akan bisa dikikis dan kemudian menjadikan bangsa kita ini bisa diperhitungkan dalam percaturan dunia internasional.

Peran pendidikan yang sangat besar membutuhkan upaya yang besar pula untuk bagaimana mengembangkannya. Pendidikan yang bisa mencetak SDM yang handal dan berakhlak, tentu adalah pendidikan yang bermutu tinggi. Banyak lembaga pendidikan yang hanya asal berdiri, tanpa memiliki orientasi dan target yang jelas, akhirnya yang terjadi adalah lulusan yang dihasilkan tidak dapat bersaing dalam kompetisi masuk di jenjang yang lebih tinggi ataupun terserap dalam dunia kerja. Dalam hal ini, menjadi tantangan yang serius bagi pemerintah, lembaga pendidikan dan masyarakat untuk dapat menciptakan pendidikan yang bermutu dan berdaya saing. Semua itu dapat terwujud dalam sebuah lembaga pendidikan yang berorientasi pada mutu produk anak didik yang siap bersaing di era global dengan bekal ilmu pengetahuan, keterampilan dan berkarakter (berakhkaqul karimah).

Saat ini, pendidikan persekolahan dihadapkan dalam berbagai tantangan, baik secara nasional maupun internasional. ${ }^{1}$ Tantangan nasional muncul dari dunia ekonomi, sosial, budaya, politik, dan keamanan. Pembangunan ekonomi saai ini masih belum beranjak dari krisis ekonomi semenjak tahun 1997/1998. Bahkan, perkembangan ekonomi pada level bawah masih dalam kondisi yang stagnan, bahkan mundur. Kehidupan sosial kemasyarakatan bangsa ini juga demikian, dimana sering terjadi kerusuhan, konflik antar daerah, pencurian, perkelahian, tawuran, free sexs pada berbagai kalangan semakin banyak terjadi dan gejala negatif kemasyarakatan lainnya semakin meningkat dari tahun ke tahun. Perkembangan budaya global saat ini malah mengikis berbagai budaya asli bangsa, khususnya budaya daerah. Dari sisi keamanan, masyarakat merasa tidak aman untuk berjalan di malam hari, atau di tempat-tempat sepi, padahal Negara ini sudah merdeka. Maka disini, pendidikan semakin ditantang untuk dapat menghasilkan lulusan yang mampu memecahkan dan membawa Indonesia pada bangsa yang lebih beradab. ${ }^{2}$

\footnotetext{
${ }^{1}$ Lihat Deni Koswara dan Cepi Triatna, Manajemen Peningkatan Mutu Pndidikan, dalam Tim Dosen Administrasi Pendidikan Universitas Pendidikan Imdonesia, Manajemen Pendidikan, (Bandung: Alfabetha, 2008), 288-289.

${ }^{2}$ Deni Koswara dan Cepi Triatna, Manajemen Peningkatan. 288 .
} 
Tantangan dunia internasional saat ini menunjukkan bahwa Indonesia akan menghadapi persaingan global, seiring dengan berlangsungnya globalisasi, khususnya dalam bidang perdagangan/ekonomi. Globalisasi mengantarkan pada perubahan lingkungan strategis bangsa di mata bangsa-bangsa lainnya di dunia ini. Selain globalisasi, perkembangan teknologi informasi juga menjadi tantangan besar bagi bangsa Indonesia. Perubahan lingkungan strategis pada tataran global tersebut tercermin dalam pembentukan forum-forum internasional seperti GATT, WTO, APEC, NAFTA, AFTA dan lain sebagainya, yang merupakan usaha untuk menyongsong perdangangan bebas, dimana akan terjadi tingkat persaingan yang sangat ketat. Pertanyaannya sekarang, apakah bangsa Indonesia ini akan siap dalam mengahadapi hal tersebut. ${ }^{3}$

Solusi untuk penyelesaian masalah nasional dan tantangan persaingan global ini mengharuskan bangsa Indonesia dapat menghasilkan Sumber Daya Manusia (SDM) yang kompeten di bidangnya dan memiliki akhlak mulia (al-akhlaq al-karimah). Untuk itu, jawaban untuk tantangan nasional maupun internasional ini adalah bagaimana pemerintah Indonesia dapat menghasilkan "pendidikan yang bermutu" untuk menciptakan manusia yang kompeten di berbagai sektor dan menjunjung tinggi adab ketimuran.

Mutu pendidikan sebenarnya menjadi pusaran kegiatan pendidikan, sehingga langkah, strategi, maupun program apapun mesti diorientasikan pada pencapaian mutu pendidikan. Maka, dalam hal ini pemerintah Indonesia telah melakukan banyak strategi untuk mengejar mutu pendidikan, sehingga kita sulit untuk menghitungnya, antara lain menetapkan desentralisasi pendidikan, merubah paradigma manajemen dengan menerapkan manajemen berbasis sekolah, memperbaiki dan menyempurnakan kurikulum, memperbaiki sistem pembelajaran, menaikkan anggaran pendidikan, meningkatkan kesejahteraan pendidik, membangun fasilitas pendidikan, menetapkan standar nasional pendidik, menggunakan sistem penjamin mutu, memperketat akreditasi dan masik banyak lagi. ${ }^{4}$ Akan tetapi, segala usaha tersebut akan sia-sia manakala tidak diikuti dengan manajemen yang baik pada tingkat sekolah atau satuan pendidikan. Artinya, sekolah sebagai eksekutor, haruslah menangkap dan melaksanakan semua kebijakan itu dengan profesional dan bertanggung jawab.

Sekolah/madrasah sebagai salah satu institusi pendidikan merupakan lembaga yang berfungsi sebagai agen perubahan untuk memecahkan semua permasalahan ini. Oleh karena itulah, dalam rangka menghasilkan mutu pendidikan yang berkualitas, dunia pendidikan

\footnotetext{
${ }^{3}$ Deni Koswara dan Cepi Triatna, Manajemen Peningkatan............. 299.

${ }^{4}$ Mujamil Qomar, Kesadaran Pendidikan; Sebuah Penentu Keberhasilan Pendidikan, (Yogyakarta: Arruzz Media, 2012), Cet.1, 48.
} 
sangat perlu untuk mengimplementasikan konsep Manajemen Mutu Total (Total Quality Management) yang dalam sejarah telah sukses mengantarkan dunia bisnis atau dunia usaha dalam menciptakan mutu produksi terbaik yang bahkan dapat melebihi kepuasan standar para pelanggan (customer)-nya.

Dalam mengimplementasikan TQM yang sudah mapan di dunia korporasi ini ke dalam lembaga pendidikan, perlu kiranya dipahami konsepnya secara matang dan dikontektualisasikan dengan kerangka organisasi lembaga pendidikan. Institusi korporasi memiliki tujuan memperoleh keuntungan finansial sebesar-besarnya dengan meningkatkan mutu barang atau jasa sebagai produk unggulannya. Begitu pula institusi pendidikan, harus pula memaksimalkan mutu layanan pendidikannya, untuk memuaskan pelanggan pendidikan, walau bukan semata-mata profit finansial tujuan akhirnya. Oleh karena itu, dalam artikel ini akan dibahas bagaimana Total Quality Management dapat diimplementasikan di lembaga pendidikan. Pembahasannya meliputi pengertian Implementasi TQM, TQM dalam dunia pendidikan, prinsip implementasi TQM dalam lembaga pendidikan, pilar TQM dalam lembaga pendidikan, langkah-langkah implementasi TQM dalam pendidikan dan uraian tentang kegagalan dalam implementasi TQM.

\section{PENGERTIAN IMPLEMENTASI TQM}

Total Quality Manajemen (TQM) atau yang biasa kita sebut dengan Manajemen Mutu Total (MMT) ini sekarang sedang marak dibicarakan dimana-mana. Sebelum membicarakan lebih lanjut bagaimana implementasi TQM dalam pendidikan, kita harus memahami dulu apa dan bagaimana pengertian "implementasi" kemudian kita sandingkan dengan pengertian Total Quality Manajemen (TQM) sehingga dapat ditarik pengertian yang utuh.

Dalam Kamus Ilmiah Bahasa Indonesia, dijelaskan bahwa pengertian “implementasi” adalah penerapan; penggunaan implemen dalam kerja; pelaksanaan; pengerjaan hingga menjadi terwujud; pengejawantahan; dan penerapan implemen. ${ }^{5}$ Pengertian ini mengandung makna bahwa ada sebuah konsep operasional yang terlebih dahulu dipahami dan dihayati, untuk kemudian diterapkan dalam tataran praksis.

Kemudian untuk TQM (Total Quality Manajemen) sendiri, Soewarso Hardjosoedarmo memberikan pengertian yang cukup menyeluruh, bahwa TQM adalah penerapan metode kuantitatif dan pengetahuan kemanusiaan untuk: 1) memperbaiki material dan jasa yang menjadi masukan organisasi, 2) memperbaiki semua proses penting dalam

\footnotetext{
${ }^{5}$ Tim Gama Jakarta, Kamus Saku Ilmiah Populer, (Jakarta: Gama Press, 2010), Cet.1, 278.
} 
organisasi, dan 3) memperbaiki upaya memenuhi kebutuhan para pemakai produk dan jasa pada masa kini dan waktu yang akan datang. ${ }^{6}$ Sedangkan Veithzal Rivai menjelaskan, bahwa TQM adalah satu himpunan prinsip-prinsip, alat-alat dan prosedur-prosedur yang memberikan tuntunan dalam praktik penyelenggaraan organisasi. TQM melibatkan seluruh anggota organisasi dalam mengendalikan dan secara kontinu, meningkatkan bagaimana kerja harus dilakukan dalam upaya mencapai harapan pengguna atau pelanggan (customer) mengenai mutu produk atau jasa yang dihasilkan organisasi. ${ }^{7}$

Dari beberapa pengertian ini, bisa kita ambil pemahaman, bahwa Implementasi Total Quality Manajeman (TQM) adalah penerapan atau pengejawantahan konsep manajemen yang melibatkan seluruh komponen dalam organisasi untuk bersama-sama berkontribusi dalam kebijakan organisasi yang berorientasi pada perbaikan mutu produk untuk kepuasan pelanggan (customer). Setiap elemen dalam organisasi lembaga pendidikan melakukan aktifitasnya dengan berdasar pada standar mutu yang telah ditentukan, mulai dari mutu pekerjaan sampai pada hasil pekerjaannya. Dalam mencapai hal tersebut, mengandaikan adanya perbaikan yang terus-menerus terhadap capaian yang telah dihasilkan, untuk diperbaiki dan ditingkatkan kualitasnya menuju mutu yang maksimal.

\section{TQM PADA LEMBAGA PENDIDIKAN}

Konsep TQM awalnya berasal dan diimplementasikan dalam dunia usaha atau bisnis. Akan tetapi, seiring berkembangnya waktu, maka konsep ini mulai di berlakukan di berbagai macam organisasi, termasuk pada lembaga pendidikan. Hal itu dikarenakan konsep ini tidak hanya bisa bekerja secara spesifik pada perusahaan, tetapi sesuai juga pada bentuk organisasi lainnya, yang berbeda di sini adalah produk yang dihasilkan, sangat tergantung pada jenis dan bentuk organisasinya. Menurut Mulyasa, ada beberapa pandangan berbeda dari para pakar tentang penggunaan konsep TQM ini dalam lembaga pendidikan. ${ }^{8}$ Taylor dan Hill (1993), serta McCulloch (1993) berargumentasi bahwa TQM merupakan konsep yang sulit di evaluasi dalam dunia pendidikan tinggi. Sedangkan Holmes dan Gerard (1995) berpendapat bahwa TQM mungkin cocok untuk fungsi pendukung (support function), tetapi tidak untuk fungsi pembelajaran sebagai inti dari penyelenggaraan pendidikan. Kemudian, di sisi lain secara jelas dijelaskan oleh Herbert, Dellana dan Bass (1995), bahwa ada empat bidang utama dalam pendidikan yang dapat mengadopsi prinsip-prinsip TQM, antara lain:

\footnotetext{
${ }^{6}$ Soewarso Hardjosoedarmo, Total Quality Manajemen, (Yogyakarta: Penerbit Andi, 2004), 1. 2009), 479

${ }^{7}$ Veithzal Rivai, Education Management; Analisis Teori dan Praktik, (Jakarta: Raja Grafindo Persada:

${ }^{8}$ E. Mulyasa, Menjadi Kepala Sekolah Profesional, Cet. 9, (Bandung: Remaja Rosdakarya, 2007), 225.
} 
1. Penerapan TQM untuk meningkatkan fungsi-fungsi administrasi dan operasi, atau secara luas untuk mengelola proses pendidikan secara keseluruhan.

2. Mengintegrasikan TQM dalam kurikulum.

3. Penggunaan TQM dalam metode pembelajaran di kelas.

4. Penggunaan TQM untuk mengelola aktivitas riset dan pengembangan.

Manajemen atau pengelolaan yang berbasis mutu ini menjadi tanggung jawab kepala sekolah/madrasah sebagai evaluator kinerja setiap bagian di bawahnya. Pada lembaga Perguruan Tinggi dan beberapa sekolah negeri dan swasta yang sudah maju, dibentuk sebuah badan atau unit yang secara khusus menangani mutu organisasi, yang biasa disebut Lembaga Penjamin Mutu. Dalam prakteknya, kepala sekolah/madrasah menggunakan lembaga ini untuk melakukan monitoring secara teknis terhadap kinerja semua komponen untuk kemudian membahasnya bersama. Dalam hal ini, pendapat Herbert, Dellana dan Bass di atas kiranya sesuai untuk diterapkan di lembaga pendidikan. Di sisi lain, pemerintah juga telah merumuskan acuan Standar Nasional Pendidikan (SNP) yang tercantum dalam UU Sisdiknas Pasal 35. Dimana standar nasional pendidikan terdiri atas standar isi, standar proses, standar kompetensi lulusan, standar tenaga kependidikan, standar sarana dan prasarana, standar pengelolaan, standar pembiayaan, dan standar penilaian pendidikan. ${ }^{9}$ Kepala sekolah/madrasah dengan Lembaga Penjamin Mutu dapat mengacu pada SNP ini dalam menjalankan manajemen mutu di lembaga pendidikannya.

Menurut Mulyasa, mengadopsi konsep TQM pada lembaga pendidikan justru merupakan suatu keharusan. ada empat alasan utama yang menjadi landasannya, antara lain: ${ }^{10}$ Pertama, para pendidik harus bertanggung jawab terhadap tugas dan fungsi mereka, karena para pendidik merupakan faktor utama bagi peningkatan sekolah. Para pendidik harus mengendalikan proses penyelesaian masalah yang berdampak pada lingkungan belajar di sekolah. Kedua, pendidikan membutuhkan proses pemecahan masalah yang peka dan fokus pada identifikasi dan penyelesaian penyebab utama yang menimbulkan masalah tersebut. Semua akar dalam masalah pendidikan bersifat sistemik, yaitu berasal dari akar masalah yang berada dari komunitas sekolah dan berimplikasi pada kegiatan belajar mengajar di sekolah itu sendiri. Ketiga, organisasi sekolah harus menjadi model organisasi belajar semua organisasi, dan keempat, melalui integrasi TQM di lembaga pendidikan, masyarakat dapat menemukan mengapa sistem pendidikan yang ada saat ini tidak berjalan dengan baik.

\footnotetext{
${ }^{9}$ Selangkapnya lihal dalam Redaksi Sinar Grafika, Undang-Undang Sistem Pendidikan Nasional (UU No. 20 Tahun 2003), Cet. 6, (Jakarta: Sinar Grafika, 2014), 23-24.

${ }^{10}$ E. Mulyasa, Menjadi Kepala Sekolah.............483-484.
} 
Seperti halnya di perusahaan, lembaga pendidikan pun memiliki struktur organisasi kelembagaan yang tiap bagiannya berjalan sesuai tupoksi masing-masing. Bagian-bagian tersebut antara lain terdiri dari pendidik (guru), tenaga kependidikan, komite, dan siswa. Semuanya dipimpin oleh kepala sekolah yang menjadi eksekutor program organisasi. Dalam manajemen yang berbasis mutu, semua komponen dalam organisasi sekolah haruslah memliki standar mutu pekerjaan pada job description masing-masing dan bekerja secara maksimal mencapai sasaran mutu tersebut. Apabila standar mutu yang menjadi acuan kinerja semua bagian dalam organisasi sekolah tercapai, maka sekolah akan mendapatkan output dan outcome yang maksimal. Mutu pendidikan yang baik, dihasilkan dari struktur organisasi sekolah yang berjalan dengan baik dan profesional, implikasinya adalah pada kepuasan masyarakat yang menjadi pelanggan jasa pendidikan.

\section{PRINSIP IMPLEMENTASI TQM DALAM PENDIDIKAN}

Sekolah yang menerapkan manajemen mutu total (TQM), sekolah tersebut harus melaksanakan program mutu pendidikan dengan berpegang pada prinsip-prinsip sebagai berikut: ${ }^{11}$

a. Berfokus pada konsumen

Setiap orang di sekolah harus memahami, bahwa setiap produk pendidikan mempunyai pengguna (customer). Setiap anggota dari sekolah adalah pemasok (supplier) dan pengguna (customer). Pelanggan disini ada dua, yaitu pelanggan internal dan pelanggan eksternal. Pelanggan internal meliputi orang tua siswa, siswa, guru, administrator, staff dan majlis sekolah. Pelanggan eksternal, seperti masayarakat, pemimpin perusahaanindustri, lembaga pemerintah, lembaga swasta, perguruan tinggi, dan lembaga keamanan.

b. Keterlibatan menyeluruh

Semua orang dalam lembaga pendidikan harus terlibat dalam transformasi mutu, manajemen harus berkomitmen dan terfokus pada peningkatan mutu.

c. Pengukuran

Dalam paradigma baru, para profesional pendidikan harus belajar mengukur mutu pendidikan dari kemampuan dan kinerja lulusan berdasarkan penggguna (customer). Melalui pengumpulan dan analisis data, para profesional pendidikan akan mengetahui nilai tambah dari pendidikan, kelemahan dan hambatan yang dihadapi, serta upaya penyempurnaannya.

\footnotetext{
${ }^{11}$ Nana Saodih Sukmadinata, Ayi Novi Jami'at dan Ahman, Pengendalian Mutu Pendidikan Sekolah Menengah; Konsep, Prinsip dan Instrumen, (Bandung: Refika Aditama, 2006), Cet. 1, 12-13.
} 
d. Pendidikan sebagai sistem

Pendidikan sebagai sistem memiliki sejumlah komponen, seperti siswa, guru, kurikulum, sarana-prasarana, media, sumber belajar, orang tua dan lingkungan. Di antara komponenkomponen tersebut, terjalin hubungan yang yang berkesinambungan dan keterpaduan dalam pelaksanaan sistem.

e. Perbaikan yang berkelanjutan

Dalam filsafat mutu, menganut prinsip, bahwa setiap proses perlu diperbaiki dan tidak ada proses yang sempurna, perlu selalu diperbaiki dan disempurnakan.

Dalam prinsip-prinsip penerapan TQM di sekolah ini, seperti yang dikutip oleh Nana Saodih, bahwa Jerome S. Arcaro (1995) membuat model visual dari sekolah yang menerapkan Total Quality Management (TQM). Model visualnya adalah sebagai berikut: ${ }^{12}$

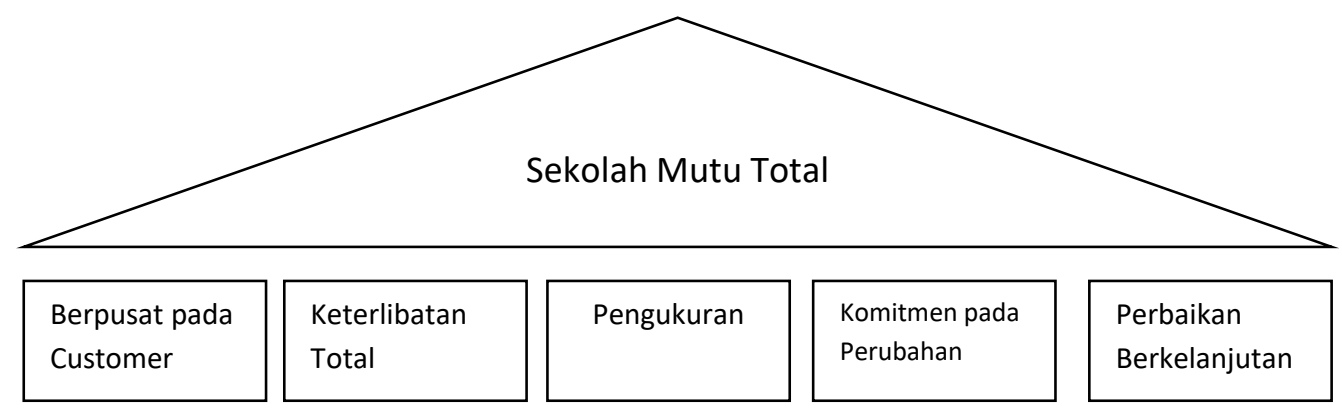

\begin{tabular}{|ll|}
\hline Visi & Kepercayaan dan Nilai \\
Misi & Tujuan Umum dan Khusus \\
& Faktor-Faktor Keberhasilan Kritis \\
\hline
\end{tabular}

Sekolah yang menerapkan mutu total ditopang oleh lima dasar, yaitu: 1) berfokus pada pengguna (pelanggan), 2) keterlibatan secara total semua anggota, 3) melakukan pengukuran terhadap kinerja, 4) adanya komitmen pada perubahan kea rah yang lebih baik, serta 5) adanya penyempurnaan secara terus-menerus. Pilar-pilar tersebut dibangun atas keyakinan dan nilai-nilai yang menjadi pegangan dalam pendidikan. Keyakinan dan nilai-nilai tersebut sejalan dengan visi dan misi sekolah, tujuan jangka panjang dan pendek, serta kriteria keberhasilan yang kritis dan selalu dievaluasi.

\section{PILAR TQM DALAM LEMBAGA PENDIDIKAN}

Dalam mengimplemantasikan TQM di lembaga pendidikan, kita tidak boleh meninggalkan lima pilar yang sangat menentukan tegaknya organisasi kelembagaan dalam

\footnotetext{
${ }^{12}$ Nana Saodih Sukmadinata, dkk. Pengendalian Mutu...........13-14.
} 
rangka menghasilkan produk yang berkualitas. Tokoh yang menemukan lima pilar dalam TQM (Total Quality Management) ini adalah Bill Grech, dia mengatakan bahwa:

"Produk adalah titik pusat untuk tujuan dan pencapaian organisasi, Mutu dalam produk tidak mungkin ada tanpa mutu di dalam proses. Mutu di dalam proses tidak mungkin ada tanpa organisasi yang tepat. Organisasi yang tepat tidak ada artinya tanpa pemimpin yang memadai. Komitmen yang kuat, dari bawah ke atas merupakan pilar pendukung bagi semua yang lain. Setiap pilar tergantung pada keempat pilar yang lain, dan kalau salah satu lemah dengan sendirinya yang lain juga lemah."13

\section{Lima Pilar TQM}

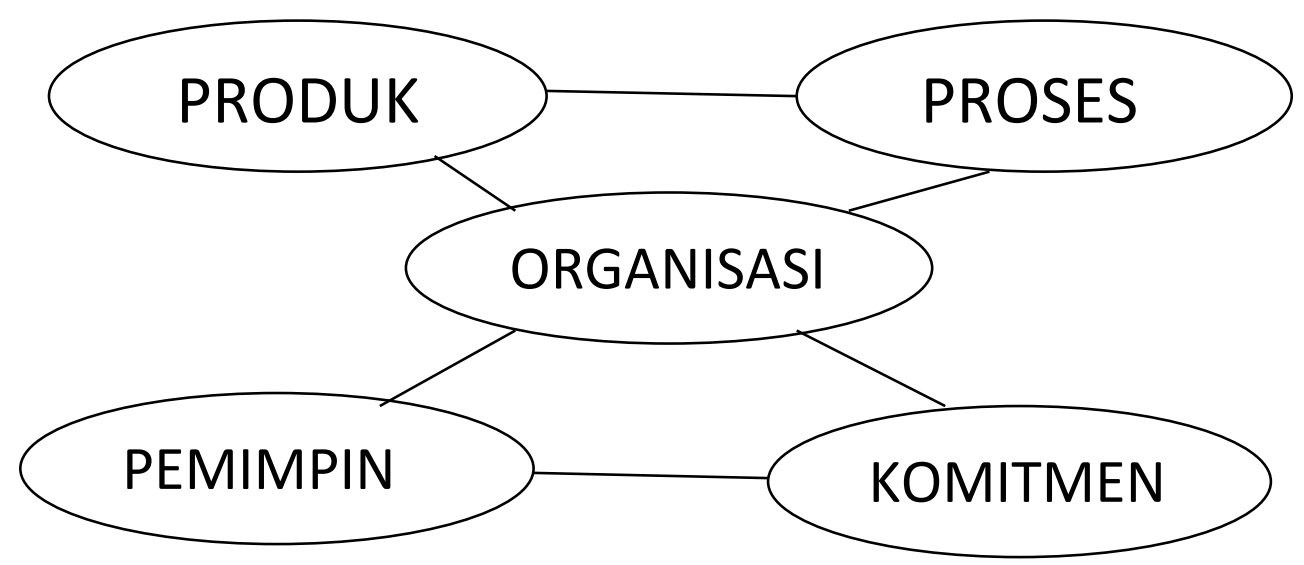

Lima pilar utama TQM disini adalah: a) adanya produk yang dihasilkan, b) proses yang dilakukan dalam menghasilkan produk dan, c) organisasi yang digerakkan oleh seorang d) pemimpin, serta adanya e) komitmen di antara para pemimpin di dalam suatu organisasi. Istilah manager dan pemimpin janganlah dicampur adukkan, karena kepemimpinan merupakan salah satu bagian dari manajemen. Manajer melaksanakan fungsi-fungsi pengawasan, termasuk dalam fungsi itu adalah perlunya memimpin dan mengarahkan. ${ }^{14} \mathrm{Jadi}$, antara pemimpin dan manajer adalah dua sisi mata uang yang tidak bisa dipisahkan. Kemudian, berjalannya lima pilar ini sangat menentukan keberhasilan implementasi TQM di lembaga pendidikan dan yang menggerakkannya tiada lain adalah pimpinan tertinggi di sekolah. Untuk itu, fungsi dan peran pemimpin untuk menggerakkan sistem mutu ini sangat penting adanya.

\section{LANGKAH IMPLEMENTASI TQM DALAM PENDIDIKAN}

Dalam Total Quality Management (TQM) atau kalau kita terjemahkan adalah Manajemen Mutu Terpadu (MMT), sekolah dipahami sebagai unit layanan jasa, yaitu

\footnotetext{
${ }^{13}$ Bill Greech, Lima Pilar Manajemen Mutu Terpadu (TQM), terj. Alexander Sindoro, (Jakarta: Binarupa Aksara, 1996), 6-7.

${ }^{14}$ M. N. Nasution, Manajemen Mutu Terpadu, (Jakarta: Ghalia Indonesia, 2001), 150.
} 
pelayanan pembelajaran. ${ }^{15}$ Jasa merupakan segenap kegiatan ekonomi yang menghasilkan output (keluaran) berupa produk (hasil karya) non fisik, yang lazimnya dikonsumsi pada saat diproduksi dan memberi nilai tambah pada bentuk (form), seperti kepraktisan, kecocokan, kepantasan, kenyamanan dan kesehatan, yang pada intinya menarik cita rasa pada pembeli pertama. Jasa pendidikan di sini merupakan jasa yang bersifat kompleks karena bersifat padat karya dan padat modal. Artinya, dibutuhkan banyak tenaga kerja yang memiliki skill khusus dalam bidang pendidikan dan padat modal karena membutuhkan infrastruktur (peralatan) yang lengkap.

Sebagai unit layanan jasa, yang dilayani sekolah adalah: 1) pelanggan internal: guru, pustakawan, teknisi dan tenaga administrasi; 2) pelanggan eksternal: pelanggan primer (siswa), pelanggan sekunder (orang tua, pemerintah dan masyarakat) dan pelanggan tersier (pemakai/penerima lulusan di perguruan tinggi maupun dunia usaha).

Dalam dunia pendidikan atau lebih tepatnya dalam lembaga pendidikan, konsep Total Quality Management (TQM) ini dapat diimplementasikan dengan beberapa fase teoritik sebagaimana klasifikasi yang disampaikan Goetsch dan Davis (1994), yaitu fase persiapan, fase perencanaan, dan fase pelaksanaan. Penjabarnnya sebagai berikut: ${ }^{16}$

1. Fase Persiapan ${ }^{17}$

Fase ini terdiri dari 10 langkah, yang mana sebelum langkah pertama dimulai, syarat utama yang harus dipenuhi adalah adanya komitmen penuh dari manajemen puncak atas waktu dan sumber daya yang dibutuhkan. Langkah-langkahnya antara lain:

a. Membentuk Total Quality Steering Committee (SC). Pimpinan puncak menunjuk staf terdekat (bawahan langsungnya) untuk menjadi anggota steering committee (SC), kemudian ia sendiri menjadi ketuanya.

b. Membentuk Tim. Steering Committee perlu mengadakan suatu sesi pembentukan tim sebelum memulai kegiatan TQM. Biasanya, langkah ini membutuhkan konsultan. Kalau dalam pendidikan, perlu didatangkan dari luar seorang konsultan pendidikan. Lebih baik sesi ini dilakukan di luar lembaga pendidikan. Agar bisa lebih fokus melakukan pembahasan tanpa mengganggu proses KBM (Kegiatan Belajar Mengajar).

\footnotetext{
${ }^{15}$ Sri Minarti, Manajemen Sekolah; Mengelola Lembaga Pendidikan Secara Mandiri, (Yogyakarta: Arruz Media, 2011), 341.

${ }^{16}$ Fandy Tjiptono dan Anastasia Diana, Total Quality Management, (Yogyakarta: Andi Offset, 2003), 67.

${ }^{17}$ Fandy Tjiptono dan Anastasia Diana, Total Quality 343-346.
} 
c. Pelatihan TQM. SC (Steering Commitee) membutuhkan pelatihan yang berkaitani dengan filosofi, teknik dan alat-alat TQM sebelum memulai aktifitas TQM. Dalam pelatihan ini, perlu mendatangkan pula seorang konsultan. Kemudian pada jangka panjangnya, juga diadakan pelatihan yang serupa sebagai follow up dari pelatihan yang pertama.

d. Menyusun Pernyataan Visi dan Prinsip sebagai Pedoman. Usaha yang pertama dalam TQM adalah penyusunan visi organisasi dan pedoman operasi organisasi.

e. Menyusun Tujuan Umum. SC menyusun tujuan umum dari organisasi (perusahaan atau sekolah) berdasarkan pernyataan visi yang telah ditetapkan.

f. Komunikasi dan Publikasi. Pemimpin puncak dan SC perlu mengkomunikasikan setiap informasi mengenai visi dan misi, prinsip-prinsip sebagai pedoman, tujuan dan konsep TQM.

g. Identifikasi Kekuatan dan Kelemahan. SC harus secara obyektif mengidentifikasi kekuatan dan kelemahan organisasi. Ini sangat penting untuk mencari pendekatan terbaik dalam pelaksanaan TQM dan bisa untuk menyoroti kekurangan-kekurangan yang harus diperbaiki. Kemudian melakukan perbaikan-perbaikan strategis ke depannya.

h. Identifikasi Pendukung dan Penolak. Langkah ini di dorong ni bisa dilakukan bersamaan dengan langkah identikasi kelemahan dan kekuatan atau sesudahnya. Di sini, SC mengidentifikasi orang-orang kunci yang mungkin menjadi penolak dan pendukung TQM. Terutama untuk anggota penolak TQM, ini dimungkinkan terjadi, karena ada kemungkinan orang tersebut belum paham dan siap dengan konsep TQM yang telah dijalankan. Dalam hal ini perlu dicari akar permasalahannya dan diadakan langkah-langkah untuk meminimalisirnya.

i. Memperkirakan Sikap Karyawan. Dengan bantuan personalia atau konsultan luar, SC perlu berusaha memperkirakan sikap karyawan pada saat ini. Pimpinan perlu memberikan judgment yang obyektif. Jika itu sudah dilakukan, akan dapat diketahui apakah TQM berjalan atau tidak.

j. Mengukur Kepuasan Pelanggan. SC perlu berusaha mendapatkan umpan balik obyektif dari para pelanggan guna menentukan tingkat kepuasan mereka. Survai kepada pelanggan sebaiknya dilakukan secara acak.

$k$. 
2. Fase Perencanaan ${ }^{18}$

Dalam fase ini ada empat (4) langkah yang harus dijalani secara sistematis. Karena semuanya membentuk sistem yang saling mempengaruhi. Adapun langkah-langkahnya adalah:

a. Merencanakan pendekatan implementasi, kemudian menggunakan siklus Plan - DoCheck - Adjust. Pada langkah ini, SC merencanakan implementasi TQM. Langkah ini bersifat terus-menerus, karena pasa saat aktivitas pembelajaran berlangsung, informasi -informasi umpan balik akan dikembalikan pada langkah ini untuk melakukan perbaikan, peyesuaian, dan sebagainya.

b. Identifikasi Poyek. SC bertanggung jawab untuk memilih proyek atau program kegiatan awal TQM, yang didasarkan pada kekuatan dan kelemahan perusahaan, personil yang terlibat, visi dan tujuan, dan kemungkinan keberhasilannya.

c. Komposisi Tim. Steering Committee membentuk komposisi tim-tim yang akan melaksanakan program TQM tersebut.

d. Pelatihan Tim. Sebelum tim yang baru terbentuk untuk melaksanakan tugasnya, mareka harus dilatih terlebih dahulu. Pelatihan yang diberikan harus mencakup dasardasar TQM dan instrumen yang sesuai untuk melaksanakan program kegiatan yang akan mereka laksanakan.

3. Fase Pelaksanaan ${ }^{19}$

a. Penggiatan Tim. Steering Committee memberikan bimbingan kepada setiap tim dan mengaktifkan mereka. Masing-masing tim menggunakan teknik TQM yang telah mereka pelajari. Mereka menggunakan siklus Plan-DO-Check-Action sebagai model proses TQM.

b. Umpan Balik Kepada Steering Committee. Masing-masing tim memberikan informasi umpan balik dari pelanggan, baik pelanggan internal maupun eksternal. Survai formal pelanggan perlu dilakukan setiap tahun. Data yang diperoleh mengenai kepuasan pelanggan dikumpulkan dan diproses secara berkesinambungan.

c. Umpan balik dari Karyawan. Setiap tim yang berada dibawah kontrol SC secara periodik memantau sikap dan kepuasan karyawan yang ada dibawahnya. Kemudian mengadakan komunikasi ntensif dengan steering committee.

d. Memodifikasi Infrastruktur. Umpan balik yang diperoleh dari langkah-langkah di atas (dari tim proyek, pelanggan dan karyawan) akan dijadikan dasar oleh steering

\footnotetext{
${ }^{18}$ Fandy Tjiptono dan Anastasia Diana, Total Quality. 347.

${ }^{19}$ Fandy Tjiptono dan Anastasia Diana, Total Quality... 348-349
} 
committee untuk melakukan perubahan yang diperlukan dalam infrastruktur lembaga pendiidkan.

Kemudian pada tataran praktis, implementasi dari konsep teoritis di atas dapat dikembangkan dalam konteks lembaga pendidikan. Kadang-kadang, terjadi kesulitan ketika menerapkan konsep TQM yang memang dari awalnya diterapkan dalam konteks perusahaan. Oleh karena itu, Edward Sallis memberikan langkah-langkah yang sangat bermanfaat bagi pengelola pendidikan untuk dapat mengimplemantasikan konsep tersebut dalam sebuah lembaga pendidikan. Adapun langkah-langkahnya antara lain sebagai berikut: ${ }^{20}$

1) Kepemimpinan dan komitmen mutu harus datang dari atas. Seluruh tokoh mutu menekankan bahwa tanpa dukungan dari manajemen senior, maka sebuah inisiatif mutu tidak akan bertahan hidup. Kepala sekolah harus menunjukkan komitmen yang kuat dan selalu memotivasi supervisor lainnya agar selalu berupaya keras dan serius dalam meningkatkan mutu ini.

2) Menggembirakan pelanggan adalah tujuan TQM. Hal ini dapat dicapai dengan usaha yang terus-menerus untuk mencapai tujuan pelanggan, baik eksternal maupun internal. Kemudian pandangan dari oaring yang tidak bergabung di institusi juga dikumpulkan. Informasi dari konsultasi ini harus disusun dan di analisis kemudian digunakan ketika membuat keputusan.

3) Menunjuk fasilitator mutu. Fasilitator mutu harus menyampaikan perkembangan mutu langsung kepada kepala sekolah. Tanggung jawab fasilitator adalah mempublikasikan program dan memimpin kelompok pengendali mutu dalam mengembangkan program mutu.

4) Membentuk kelompok pengendali mutu. Kelompok ini harus merepresentasikan perhatian-perhatian kunci dan harus merupakan representasi dari tim manajemen senior. Perannya adalah untuk mengarahkan dan mendorong proses peningkatan mutu. Ia adalah pengembang ide sekaligus inisiator proyek.

5) Menunjuk koordinator mutu. Dalam setiap inisiatif dibutuhkan orang-orang yang memiliki waktu untuk melatih dan menasehati orang-orang lain. Koordinator tidak mengerjakan seluruh proyek mutu. Perannya adalah untuk membantu dan membimbing tim dalam menemukan cara baru dalam menangani dan memecahkan masalah.

${ }^{20}$ Edward Sallis, Total Quality Management in Education; Manajemen Mutu Pendidikan, (Yogyakarta: IRCiSoD, 2012), Cet. 16, 245-253. 
6) Mengadakan seminar manajemen senior untuk mengevaluasi program. Pelatihan khusus dalam pendekatan strategis terhadap mutu mungkin dibutuhkan. Hal itu dikarenakan mereka perlu memberi contoh pada tim dalam memajukan institusi.

7) Menganalisa dan mendiagnosa situasi yang ada. Proses ini tidak bisa diremehkan, karena ia sangat menentukan seluruh proses mutu. Seluruh institusi perlu menjelaskan dimana posisinya dan mana arah yang mereka tuju.

8) Menggunakan contoh-contoh yang sudah berkembang di tempat lain. Ini bisa berupa adaptasi dari salah satu "guru" mutu atau seorang tokoh pendidikan khusus atau yang mengadaptasi pola TQM yang diterapkan di tempat lain untuk kemudian diambil sisi positifnya dan bisa diterapkan di sekolah yang dipimpin.

9) Mempekerjakan konsultan eksternal. Langkah ini sangat baik dilakukan, teruama jika ingin mencapai tingkat standar mutu internasional, semacam ISO. Akan tetapi biayanya cenderung mahal, hanya sekolah yang dengan sumber dana memadai yang bisa melakukan itu.

10) Memprakarsai pelatihan mutu bagi para staf. Pelatihan adalah tahap implementasi awal yang sangat penting. Oleh karena itu setiap orang perlu dilatih dasar-dasar TQM. Staf membutuhkan pengetahuan tentang beberapa alat kunci yang mencakup tim kerja, metode evaluasi, pemecahan masalah, dan teknik pembuatan keputusan.

11) Mengkomunikasikan pesan mutu. Strategi, relevansi dan keuntungan TQM harus dikomunikasikan secara efektif. Program jangka panjang harus dirancang seara jelas. Staf harus mendapatkan informasi atau laporan secara regular melalui surat kabar atau jurnal.

12) Mengukur biaya mutu. Mengetahui biaya dalam implementasi program mutu merupakan hal yang penting. Demikian juga dengan biaya pengabaian mutu. Biaya tersebut bisa muncul dari berkurangnya jumlah pendaftar, kegagalan murid, kerusakan reputasi dan sebagainya. Pengujian terhadap biaya pengabaian mutu itu juga perlu dilakukan, agar disatu sisi tetap berpegang pada program mutu, di sisi lain juga ada kontrol terhadap biaya yang dikeluarkan.

13) Mengevaluasi program dalam interval yang teratur. Evaluasi teratur harus menjadi bagian yang integral dalam program mutu. Evaluasi itu harus dilakukan eman bulan sekali secara teratur dan hasil dari evaluasi itu benar-bernar dijadikan bahan pertimbangan berjalannya program selanjutnya.

\section{KEGAGALAN DALAM IMPLEMENTASI TQM}


Banyak lembaga pendidikan yang mampu menerapkan TQM, tetapi tidak sedikit pula yang gagal menerapkannya. Faktor-faktor yang menjadi penghalang bagi perusahaan atau sekolah dalam menerapkan TQM. Hal-hal yang perlu dihindari karena dapat menggagalkan proses TQM adalah sebagai berikut: ${ }^{21}$

a) Kesenjangan komitmen manajemen puncak

Manajemen puncak (kepala sekolah dan para wakilnya) tidak menghayati sepenuhnya arti TQM, sehingga tidak mampu pula membangun struktur organisasi yang diperlukan untuk pelaksanaan TQM dan tidak mampunya membentuk sistem hadiah (reward system) yang mendorong dilaksanakannya TQM.

b) Salah memfokuskan perhatian

Salah memfokuskan pada salah satu butir-butir atau sistematika TQM saja, sehingga mengabaikan butir-butir yang lain. Seharusnya semua langkah-langkah dalam TQM dilakukan secara urut dan lengkap. Karena semua bagaikan sistem yang saling mempengaruhi.

c) Tidak tersedianya karyawan yang memadai dan mendukung

Keberhasilan TQM didasari oleh karyawan yang siap dan mempunyai komitmen akan tanggung jawab menjalani tugasnya pada manajemen mutu terpadu. Komitmen tidak timbul hanya melalui maklumat atau pengumuman resmi, tetapi memerlukan informasi kepada karyawan tentang tujuan TQM dan pentingnya TQM bagi perusahaan mereka.

d) Hanya mengandalkan pelatihan semata-mata

Setelah latihan dilaksanakan, selanjutnya adalah bagaimana hasil pelatihan itu dilaksanakan (by action). Berarti ini memerlukan hal-hal lain, seperti perbaikan mutu, menciptakan operasi yang lebih baik, jelas dan mengerti para karyawan.

e) Harapan memperoleh sesaat, bukan hasil jangka panjang

Pelaksanaan TQM memerlukan perubahan organisasi secara mnyeluruh dan budaya kerja. Perubahan tidak dapat segera terjadi dalam waktu singkat dan cepat, bahkan hasilnya mungkin baru dapat dirasakan satu sampai dengan dua tahun. Ketekukan dan kesabaran tim TQM di sini sangat diperlukan.

f) Memaksa mengadopsi suatu metode padahal tidak cocok

Tidak semua teknik dalam TQM cocok di berbagai lembaga. Hal ini perlu penyesuaian, bila tidak, hanyalah kegagalan yang diperoleh. Pimpinan sekolah perlu secara luwes dalam menerapkan sistem TQM, lalu mereka mempunyai kemauan untuk menelusuri

${ }^{21}$ Suyadi Prawirosentono, Filosofi Baru tentang Manajemen Mutu Terpadu Abad 21, (Jakarta: Bumi Aksara, 2007), 96-97. 
kembali berbagai kekurangan secara tepat. Sehingga, dapat menentukan apakah sesuatu yang telah diadopsi itu cocok atau perlu penyesuaian dengan kondisi serta situasi sekolah atau perusahaan mereka.

\section{SIMPULAN DAN SARAN}

Total Quality Management (TQM) atau yang biasa di sebut di Indonesia sebagai Manajemen Mutu Total (MMT) ini sangat perlu diadopsi, diterapkan dan dikembangkan di dunia pendidikan, lembaga pendidikan, khususnya lagi sekolah. Hal itu adalah sebuah keniscayaan, karena seiring kemajuan IPTEK dan Sumber Daya Manusia (SDM), maka karyawan akan semakin siap untuk diterapkannya konsep manajemen ini. Akan tetapi, TQM ini bisa maksimal pada sekolah-sekolah yang memang sudah besar, dengan fasilitas yang lengkap dan memadai. TQM bisa dilakukan juga di sekolah yang masih berkembang di daerah-daerah pedesaan, dengan catatan perlu adanya usaha ekstra keras dari kepala sekolah yang bersangkutan untuk menyatukan visi, mengadakan pemahaman tantang konsep mutu dan memaksimalkan pendanaan untuk menggaji para karyawannya dengan cukup.

Konsep TQM ini tidak akan mencapai tujuannya apabila prinsip-prinsip dalam TQM sendiri tidak dipegang dengan teguh. Karena TQM ini sangat berhubungan dengan integritas dan loyalitas karyawan, maka dalam jiwa pemimpinnya sampai karyawan tingkat paling bawah, haruslah tertanam akan pentingnya "mutu" dalam kualitas tugas mereka masingmasing. Jika ini sampai melenceng atau goyah, maka proses TQM akan berjalan terseok dan tujuan TQM tidak akan pernah tercapai.

Pilar-pilar TQM yang antara lain adanya produk yang dihasilkan, proses yang dilakukan dalam menghasilkan produk dan organisasi yang digerakkan oleh seorang pemimpin, serta adanya komitmen di antara para pemimpin di dalam suatu organisasi. Nah, semua komponen ini membentuk satu sistem TQM yang saling mempengaruhi dan digerakkan oleh salah satu pilarnya, yaitu pemimpin. Artinya, pemimpin disini harus benarbenar piawai memainkan peranannya dalam menjalankan sistem ini untuk mencapai tujuan program TQM yang telah dicanangkan.

Implemantasi TQM pada dunia pendidikan dan dunia bisnis memiliki perbedaan yang esensial. Hal itu bisa dilihat dari produk dan tujuannya. Produk pada sekolah adalah lulusan yang siap dengan ilmu pengetahuan plus prakteknya dan adanya sikap atau attitude yang baik pada lulusannya. Indikator keberhasilannya adalah lulusan dapat diterima di perguruan tinggi yang berkualitas, dapat diterima di dunia kerja dan bisa menjalani segala peran hidupnya dengan sikap yang baik dimana pun dia berada. Sedangkan, jika perusahaan bisnis adalah ada 
pada produk barang atau jasa yang berkualitas dan indikatornya adalah adanya keuntungan yang sebesar-besarnya pada perusahaan. Akan tetapi, dalam langkah implementasinya, keduanya memilki tahapan yang sama, tentunya dengan analogi-analogi yang tepat.

Kegagalan dalam implentasi TQM bisa disimpulkan secara menyeluruh adalah dikarenakan adanya inkonsistensi dari beberapa atau semua komponen mutu yang ada di sekolah. Oleh karena itu, tidak boleh ada satupun komponen mutu atau tim TQM yang asal kerja dalam melaksanakan tugasnya hingga melakukan kesalahan. Kalaupun itu terjadi, sang pemimpin di sekolah harus segera mengadakan perbaikan dengan secepatnya, agar proses mutu itu terus berlangsung dan berkembang sedikit demi sedikit tanpa terhenti dengan adanya inkonsistensi tersebut.

\section{DAFTAR PUSTAKA}

Fandy Tjiptono dan Anastasia Diana, Total Quality Management, (Yogyakarta: Andi Offset, 2003).

Greech, Bill, Lima Pilar Manajemen Mutu Terpadu (TQM), terj. Alexander Sindoro, (Jakarta: Binarupa Aksara, 1996).

Hardjosoedarmo, Soewarso, Total Quality Manajemen, (Yogyakarta: Penerbit Andi, 2004).

Jakarta, Tim Gama, Kamus Saku Ilmiah Populer, (Jakarta: Gama Press, 2010), Cet.1.

Minarti, Sri, Manajemen Sekolah; Mengelola Lembaga Pendidikan Secara Mandiri, (Yogyakarta: Arruzz Media, 2011).

Mulyasa, Encho, Menjadi Kepala Sekolah Profesional, (Bandung: Remaja Rosdakarya, 2007), Cet. 9.

Nasution, M.N., Manajemen Mutu Terpadu, (Jakarta: Ghalia Indonesia, 2001).

Prawirosentono, Suyadi, Filosofi Baru tentang Manajemen Mutu Terpadu Abad 21, (Jakarta: Bumi Aksara, 2007).

Qomar, Mujamil, Kesadaran Pendidikan; Sebuah Penentu Keberhasilan Pendidikan, (Yogyakarta: Arruzz Media, 2012), Cet.1.

Rivai, Veithzal, Education Management; Analisis Teori dan Praktik, (Jakarta: Raja Grafindo Persada: 2009).

Sallis, Edward, Total Quality Management in Education; Manajemen Mutu Pendidikan, (Yogyakarta: IRCiSoD, 2012), Cet. 16. 
Saodih Sukmadinata, Nana, Ayi Novi Jami'at dan Ahman, Pengendalian Mutu Pendidikan Sekolah Menengah; Konsep, Prinsip dan Instrumen, (Bandung: Refika Aditama, 2006).

Sinar Grafika, Redaksi, Undang-Undang Sistem Pendidikan Nasional (UU No. 20 Tahun 2003), Cet. 6, (Jakarta: Sinar Grafika, 2014).

Universitas Pendidikan Indonesia, Tim Dosen Administrasi Pendidikan, Manajemen Pendidikan, (Bandung: Alfabetha, 2008). 